\title{
LEGAL DEVELOPMENTS IN CROSS-BORDER MARRIAGES AMONG MALAY MUSLIMS IN MALAYSIA
}

\author{
Noraini Md. Hashim* \\ Nora Abdul Hak* \\ Muhamad Helmi Md Said ${ }^{* * *}$
}

\begin{abstract}
Cross-border marriages have received a considerable amount of attention in recent years. Patterns and characteristics of crossborder marriages appear to differ widely among the world's region and races. This article aims to discuss the legal development and history of cross-border marriages from the perspective of Muslim Malay couples in Malaysia and generally, under the English law. An analytical legal approach is used in this study to explore the legal developments in such cross-border marriages. The findings of this work are expected to fill the gap in the legal literature on marriages in Malaysia and also provide reference for designing a new improved policy and regulatory framework to deal with the problem.
\end{abstract}

Keywords: cross-border marriages, malay muslims, Islamic family law, legal developments

Assistant Professor, Ahmad Ibrahim Kulliyyah of Laws, International Islamic University Malaysia: E-mail : norainim@iium.edu.my

${ }^{* *+\dagger}$ Professor, Ahmad Ibrahim Kulliyyah of Laws, International Islamic University Malaysia: E-mail : ahnora@iium.edu.my

*** Ph.D candidate, Ahmad Ibrahim Kulliyyah of Laws, International Islamic University Malaysia: E-mail: mhelmisaid@gmail.com 


\title{
PERKEMBANGAN PERUNDANGAN PERKAHWINAN MERENTASI SEMPADAN BAGI PASANGAN MUSLIM DI MALAYSIA
}

\begin{abstract}
ABSTRAK
Perkahwinan merentasi sempadan sentiasa mendapat perhatian kebelakangan ini. Dengan pertambahan jumlah perkahwinan merentasi sempadan dan kurangnya penyelidikan dalam subjek ini, maka, tujuan makalah ini ditulis adalah untuk membincangkan mengenai perkembangan perundangan dan sejarah perkahwinan merentasi sempadan menurut apa yang berlaku di Malaysia di kalangan pasangan muslim dan di bawah undang-undang Inggeris. Kajian ini mengguna pakai metod analisis dalam membincangkan isu-isu berkaitan perkembangan perundangan perkahwinan merentasi sempadan ini. Hasil kajian adalah diharapkan dapat menjadi penulisan undang-undang berkaitan perkahwinan di Malaysia dan sebagai rujukan untuk mencadangkan satu polisi baru dan pelaksanaan rangka kerja yang berkaitan dengan bentuk perkahwinan seperti ini.
\end{abstract}

Kata kunci: perkahwinan merentasi sempadan, orang-orang Islam Melayu, undang-undang keluarga Islam dan perkembangan undang-undang.

\section{INTRODUCTION}

Marriage does not only make a relationship legitimate, but also brings with it all the consequential rights, obligations and privileges between the contracting parties. Aside from that it also creates relations of consanguinity and affinity. It is therefore clear that in order for a marriage to be valid, it must be solemnised in accordance with the law in that particular country. For Muslims in Malaysia, the Malaysian government has provided clear guidelines on the forms of 
marriages found in the enactments of Islamic Family Laws in each state.

As a social institution in Islam, marriage is regarded important as it plays a crucial role in the formation of a family, the nucleus in a Muslim society. The issue of cross-border marriages is not new in today's society. Its causes and solutions are entangled in various polemics in societal discourse. A cross-border marriage is regarded as one that departs from and certainly is taken to disregard, the culture and norms of the Malay Muslim society and is even seen as an act of disrespect. The main destination for cross-border marriages chosen by Malay Muslim couples in Malaysia is either Thailand or Indonesia. The problem of cross-border marriages is not unique to Malaysia. In fact, historically, several places in the world have had similar problems and one clear example could be seen in the cross-border marriages of Gretna Green in the United Kingdom. ${ }^{1}$ After years of facing problems, the government of the United Kingdom decided to make reforms in the laws of marriage in order to overcome this situation. This is the reason why the position in the UK is cited so as to examine the changes that were made in the UK so as to see what Malaysia can learn from such experience.

This article first discusses the development of cross-border marriages from the perspectives of Malaysian law. For the Muslims in Malaysia, reference will be made to Islamic Family Laws. The Islamic Family Laws of every state contain no specific provisions relating to cross-border marriages. Cases concerning cross-border marriages are treated under the laws relating to "marriages without permission". Generally, the term "Kahwin Luar Sempadan" or crossborder marriage refers to an act of marriage that is not recognised by customs or law and is viewed unfavourably by the religion. ${ }^{2}$ The layman normally refers to it as "kahwin lari"3 or "kahwin koboi"

Henry Campbell Black, Black's Law Dictionary $4^{\text {th }}$ Edition( St Paul. Minn.West Publishing Co,1968), 907.

2 Noraini Md Hashim, "Cross-border Marriage (CBM) : A Comparative Study On The Profiles And Factors Of Cross-border Marriages Among Malays In Malaysia" In National Seminar On Malaysia Family Policy 2011. Bridging Research And Policy On The Family, Children And Adolescent, 14-15th September 2011, Dewan Al Farabi, Faculty Of Human Ecology UPM, 3

3 Gavin W. Jones, "Malay Marriage and Divorce in Peninsular Malaysia: Three Decades of Change," Population and Development Review, 7(2) (June, 1981), ) 261. Gavin has mentioned that kahwin lari is an irregular common practice of registering marriages and divorce over the border. 
referring to the ad hoc nature of such marriage. ${ }^{4}$ The Muslim couple who commits this act can be categorised as a local couple (both of whom who are Malays) and between a local (male or female Malay) with a non-local party and can be in the form of either a monogamous or polygamous marriage. ${ }^{5}$

After dealing with the Malaysian position, the article will then look into the position in England, where a similar phenomenon known as the "Gretna Green" marriages was also a problem. According to Black's Law Dictionary, a "Gretna Green" marriage is a marriage celebrated at Gretna, in Dumfries, (bordering country of Cumbria) in Scotland. ${ }^{6}$ The law of Scotland considered that a valid marriage may be contracted by consent alone without any need for formalities. $^{7}$ The introduction of Lord Hardwicke's Act 1753 (effective as of 1754) had created difficulties for couples to marry. ${ }^{8}$ Thus, some decided to run away, and marry in Scotland, where a marriage ceremony could even be performed by the village blacksmith. ${ }^{9}$ According to Stuart Stein, ${ }^{10}$ these types of cross-border marriages are also known as fleet marriages. ${ }^{11}$ These types of marriages are characterised by the act of young couples, crossing the border in order to marry without due consideration given to the

$4 \quad$ Noraini Md Hashim, "Kahwin lari: Tinjauan umum (Cross-border Marriage : A general overview)", Paper presented at the seminar Isu-Isu Mahkamah Syariah, Kahwin Lari: Masalah dan penyelesaiannya, Moot Court, International Islamic University Malaysia, February 2003, 1. The writer has used the term " Perkahwinan Merentasi Sempadan which can interchangeably be used as crossborder marriages too.

5 Noraini Md Hashim, Registration of Marriage in Malaysia: A Socio Legal Study of Runaway Marriages among Muslims (Unpublished Ph.D. thesis, International Islamic University Malaysia, 2009)

Henry Campbell Black, n.1

Ibid.

Stephen Cretney et al., Principles of Family Law, $\left(7^{\text {th }}\right.$ Edition, Thompson Sweet \& Maxwell, 2003)11. This act was introduced to regulate irregular marriage in Common Law and to secure publicity that no marriage should be valid unless it was solemnised according to the rites of the church.

9 Stuart J Stein, "Common Law Marriage: Its History and Certain Contemporary Problems," Journal of Family Law, (1969-1970): 274 (retrieved via $\mathrm{http} / /$ Heinonline.org as on 28.7.2013).

10 Ibid.

11 A fleet marriage was an irregular marriage or clandestine marriage that has taken place in England before the introduction of Lord Harwicke's Act 1753. See "fleet marriage", Wikipedia, Last modified on 28 July 2014 at 19:25 http://en.wikipedia.org/wiki/fleet_marriage. 
consequences of the marriage. Such marriages are often contracted either in an infatuated state or by intimidation of threats, or marriages which are hastily concluded due to an unsuitable match or clandestine alliances. This problem was later dealt with effectively in England through the enactment of laws, which emphasised on the need for the registration of marriages. It is due to this reason that the position in England is examined so as to provide a guide on how the persistent problem of cross-border marriages in Malaysia could be settled.

Nevertheless, in considering the English position, care must be taken so as to ensure that the Shari' ah legal position on the validity of marriage is not compromised. Instead, what could be adopted is a more stringent enforcement mechanism of existing laws relating to the registration of marriages as well as the need for a higher penalty. This would inevitably lead to the need to expand the jurisdiction of the Shari'ah Courts in Malaysia.

\section{CROSS-BORDER MARRIAGES AMONG MUSLIMS IN MALAYSIA}

Marriage for the Muslim Malays of Malaysia is an inter-mingling of traditional custom and the Shari'ah. It may be pointed out that under classical Islamic law, the registration of a marriage does not determine the validity of a marriage. However, according to the Islamic Family laws codified in Malaysia, registration is merely a procedure to keep track of the existence of a valid marriage. This requirement is a modification introduced into this country based on the English system. ${ }^{12}$ The earliest law known to govern matrimonial matters and introduce the requirement for the registration of marriages was the Mohamedan Ordinance 1880 in the Straits Settlement. ${ }^{13}$ The law was later extended to the Federated Malay States, whereby Perak was the first state to implement the Registration of Muhammadan Marriages and Divorces in $1885 .{ }^{14}$ There was a series of laws introd.... all the states in Malaysia until un prescm uay wruce un soranme Family Law (Federal Territories) Act and Islamic Family Laws

\footnotetext{
12 Mahmood Zuhdi, "Pentadbiran Undang-Undang Keluarga Islam di Malaysia," Jurnal Syariah Volume 3, No. 2, (1996): 211.

13 Ibid, 212.

14 Ibid.
} 
Enactments in the respective states have continued to make marriage registration compulsory.

However, unlike the position in England, the requirements for the registration of marriages in the Act and Enactments does not validate the marriage per se. Such requirements only guarantee that the only marriages that have been registered thereunder are recognised by the law. ${ }^{15}$ Hence, if a marriage is valid according to Islamic law but not registered, the marriage is nonetheless valid. The couple could however be liable for failing to register the marriage which is punishable with a fine not exceeding RM1,000. Similarly, if the marriage is invalid according to Islamic law but is nonetheless registered, the person who registered the marriage may have committed an offence punishable under section 40 of Islamic Family Law (Federal Territories) Act, 1984. Therefore, the non-registration of a marriage will not affect the validity of a marriage. ${ }^{16}$

In Malaysia, cross-border marriages have been associated with marriages solemnised in the Changwat (province) of Southern Thailand namely Narathiwat, Patani, Satun, Songkla, and Yala. This is due to the location of the Northern and the Eastern states of Malaysia, namely Kedah, Perlis, Perak, Terengganu, and Kelantan bordering Southern Thailand which are separated only by customs and immigration checkpoints. ${ }^{17}$ From Perlis to Changwat Songkla, the most well-known land route is through Padang Besar. ${ }^{18}$ Meanwhile, access to Changwat Satun is through Wang Kelian and there are two routes to Changwat Danok namely, through Bukit Kayu Hitam and Changloon, in Kedah. ${ }^{19}$ As for the state of Kelantan, it is through Sungai Kolok (Golok), in Rantau Panjang or Tok Bai, in Tumpat. $^{20}$ As for the sea-route, Kuala Perlis is the primary route to reach Satun or Padang Panjang. Another route is through a boat ride from Langkawi. ${ }^{21}$ Among the reasons that have prompted couples to

15 Section 34, Islamic Family Law Federal Territories (Kuala Lumpur, Labuan and Putrajaya) Act 1984.

16 Ibid.

17 Md. Akhir Hj. Yaacob and Siti Zalihah Md Nor, Beberapa Aspek Mengenai Enakmen Keluarga Islam di Malaysia. $1^{\text {st }}$ Edition, (al Rahmaniah, Petaling Jaya, 1989).51.

18 Ibid.

19 Ibid.

20 Ibid.

21 Ibid. 
marry by way of Wali Raja ${ }^{22}$ in Thailand include the existence of either blood relations or business or social relationship between the citizens of both countries and the cumbersome procedures enforced by the authorities in Malaysia to solemnise a marriage.

Before the enforcement of the comprehensive Islamic Family Law enactments (other states in Peninsular Malaysia) and Act (only in the Federal Territories) in the early 1980s, the administration of the Islamic Family Laws in various states were deficient in many aspects and there were differences in the law enacted and applied in the various states. ${ }^{23}$ For example in the case where the guardian $\left(\right.$ wali $\left.^{24}\right)$ refuses to give his permission to the marriage of his daughter, the bride and groom may go to other parts of Malaysia to contract their marriage by the usage of Wali Raja on the ground that the distance of the place of marriage solemnised from the wali's place is more than two marhalah. ${ }^{25}$

However, the Islamic Family Law Enactments and Act have clearly provided that no marriage shall be solemnised except in the kariah masjid ${ }^{26}$ or village mosque in which the woman resides, with the Registrar of Muslim Marriages or Shari'ah Judge giving permission to marry. ${ }^{27}$ Any marriage to be solemnised elsewhere, whether in the Federal Territories or any state must also get permission from the Registrar of Muslim Marriages ('Registrar') and

22 According to Section 2 of Islamic Family Federal Territories (Kuala Lumpur, Labuan and Putrajaya) Act 1984, Wali Raja is an Islamic legal term that can be defined as a guardian of marriage authorized by the Ruler to give away in marriage a woman who has no guardian of marriage by blood ties. Ahmad Ibrahim, "Islamic Law in Malaysia since 1972", in "Developments in Malaysian Law", $1^{\text {st }}$ edition, ( Pelanduk Publications, 1992) 298.

24 According to Section 2 of Islamic Family Federal Territories (Kuala Lumpur, Labuan and Putrajaya) Act 1984, wali (guardian) can be divided into two categories for the purpose of the marriage, Wali Mujbir and Wali Raja. Wali Mujbir means the father or paternal grandfather and above.

25 Noraini Md Hashim, Registration of Marriage in Malaysia: A Socio Legal Study. Marhalah is a distance (which is equivalent to 96 kilometres) according to Islamic law in order to legalise certain acts.

26 According to Section 2 of Islamic Family Federal Territories (Kuala Lumpur, Labuan and Putrajaya) Act 1984, kariah masjid means in relation to a mosque, the area and the boundaries of which are determined under section 75 of the Administration Act.

27 Section 16 (1), Islamic Family Law (Federal Territories of Kuala Lumpur, Labuan and Putrajaya) Act 1984. 
the Shari'ah Judge. ${ }^{28}$ At the same time, the person solemnising the marriage must be a person appointed by the Yang DiPertuan Agong. ${ }^{29}$ Failure to observe these requirements is considered as an offence under section 40 (2) Islamic Family Federal Territories (Kuala Lumpur, Labuan and Putrajaya) Act 1984. It can therefore be inferred here that Muslim couples who are involved in cross-border marriages will be subjected to the penalties provided under this section. ${ }^{30}$ The case of Syarie Prosecutor $v$ Aziz Bin Johari ${ }^{31}$ illustrates the punishment of those involved in cross-border marriages. In this case, the first accused was charged for contracting the marriage with Azma Bt Mohamed Adnan in Yala, Southern Thailand without the permission of the court. In this case, the accused was found guilty by the court and was punished with RM1,000.00 fine.

The increasing number of couples marrying without the permission of the authorised body such as Shari'ah Court is due to the introduction of the new Islamic Family Law Enactments and Act in Malaysia. ${ }^{32}$ It leads to the question concerning the legal status of the marriage solemnised in Thailand or elsewhere. This type of marriage is the main focus of the state authority. According to Noraini Md Hashim, any person who solemnised their marriage inside or outside of Malaysia without the permission of the Registrar is said to practice a cross-border marriage. ${ }^{33}$ Every marriage must be registered according to state laws or enactments; nevertheless, the registration is not meant to determine the validity of the marriage. For example, according to section 34 of Islamic Family Law Federal Territories (Kuala Lumpur, Labuan and Putrajaya) Act 1984 ('the Islamic Family Law (FT) Act 1984'), "Nothing in this Act or rules made under this Act shall be construed to render valid or invalid any marriage that

28 Section 20 (1), Islamic Family Law (Federal Territories of Kuala Lumpur, Labuan and Putrajaya) Act 1984.

29 Section 28, the Islamic Family Law (Federal Territories of Kuala Lumpur, Labuan and Putrajaya) Act 1984. According to Article 32 of Federal Constitution, Yang Dipertuan Agong is a Supreme Head of Federation.

30 Section 40(2), 123, 133 and Section 35 of the Islamic Family Law (Federal Territories of Kuala Lumpur, Labuan and Putrajaya) Act 1984.

31 (2008) 3 Sha Law Reports 111.

32 Noraini Md Hashim, "Registration of Marriage in Malaysia: A Socio Legal Study of Runaway Marriages among Muslims" (Ph.d thesis, International Islamic University Malaysia, 2009), 127

33 Noraini Md Hashim, "Kahwin lari: Tinjauan umum (Cross-border Marriage : A general overview)”. 
otherwise is invalid or valid, merely by reason of its having been or not having been registered."

Thus, a marriage is still valid according to the Islamic Law even without registration. According to section 25 of Islamic Family Law (FT) Act 1984, a marriage after the appointed date of every person resident in the Federal Territory and of every person living abroad who is resident in the Federal Territory shall be registered in accordance with the Act.

Section 19 of the Islamic Family Law (FT) Act 1984, provides that no marriage shall be solemnised unless a permission to marry has been given:

1. by the Registrar under section 17 or by the Syariah Judge under section 18, where the marriage involves a woman resident in the Federal Territory; or

2. by the proper authority of a State, where the marriage involves a woman resident in that State.

From the provisions stated above and particularly under section 40 (2) of Islamic Family Law (FT) Act 1984, one can conclude that where any marriage is carried out without the permission of the Registrar, the parties involved will be punished with a fine of not more than one thousand Ringgit Malaysia or with imprisonment of not more than 6 months or both.

The importance placed on the need to register cross-border marriages has been made within the Islamic Family Law (FT) Act 1984 itself. This can be seen in section 31(1) of the Islamic Family Law ( FT) Act 1984, where any person who is a resident of the Federal Territory has contracted a valid marriage according to Islamic Law abroad, not being a marriage registered under section 24 , the person shall, within six months after the date of the marriage, appear before the nearest or most conveniently available Registrar of Muslim Marriages, Divorces, and Reconciliation abroad in order to register the marriage, and the marriage, upon being registered, shall be deemed to be registered under this Act. From this section, one can infer that a marriage must be registered within 6 months before the nearest Registrar as stated in Section 31 of the Islamic Family Law (FT) Act 1984; however, a marriage that is not registered is still valid according to Islamic Law if the spouses fulfill all the conditions that have been prescribed by Islamic Law. 
Thus, in Malaysia, the laws and the Fatwa Committee of the National Council of Islamic Religious Affairs Malaysia ${ }^{34}$ still consider the marriage valid if the location exceeds two marhalah (equivalent to $96 \mathrm{~km}$ ) and fulfils the conditions that have been prescribed by the laws and rulings. The $52^{\text {nd }}$ Conference of the Fatwa Committee of the National Council of Islamic Religious Affairs Malaysia held on July 1, 2002, in deliberating on the runaway marriages to Southern Thailand, decided that a marriage outside the country is valid provided that it complies with the requirements imposed by Islamic Law, there is no court decision preventing the woman from getting married on legal grounds, the distance is more than two marhalah and such marriage is solemnised by a Wali Hakim legally empowered under the law of that country. ${ }^{35}$ With due regard to public interest, it is opined that the Fatwa Committee is correct in considering such marriage as valid if the location exceeds two marhalah. All Muslim marriages whether solemnised in Malaysia or elsewhere must be registered. In the case of cross-border marriages, the most affected persons are the groom's children and wives. Therefore, if the marriage cannot be registered in Malaysia, the welfare of the children and wives will not be protected.

\section{CROSS-BORDER MARRIAGES UNDER THE ENGLISH LAW}

In England, the Church had a great influence on family institutions. During the seventeenth century, the bishop was appointed to become the judge. Later on, William the Ruler separated the Religious Tribunal $^{36}$ from the law tribunal and the consequence of the

34 The National Council for Islamic Affairs was established during the $18^{\text {th }}$ Conference of Rulers on the $1^{\text {st }}$ July 1969 . This council is established to set up the effective and standard coordination among states in matters of Muslim affairs administration in Malaysia. After the establishment of this Council, National Fatwa Committee has been set up by virtue of section 14 of the Council Regulations. The function of this Fatwa Committee is to deliberate, decide and issue any rulings on any matters related to Islam.

35 "The 52 nd Conference of the Fatwa Committee of the National Council of Islamic Religious Affairs Malaysia on Kahwin Lari di Selatan Thailand," e.fatwa, last modified 08 April 2015, http://www.e.fatwa.gov.my/fatwa kebangsaan/kahwin lari.

36 According to Edward J.Stein, religious tribunal referred to spiritual tribunal whereby its court had exclusive jurisdiction over matrimonial matters, whereas Law tribunal referred to royal court. The Royal court had a power to trial all 
separation was that the ecclesiastical court had exclusive jurisdiction in England. Moreover, since the Council of Trent was not applicable in England, common-law marriages continued after $1563 .{ }^{37}$

The first significant change came in 1587 when Queen Elizabeth 1 ordered that the records be kept in official books. She also ordered that ministers submit a copy of all register entries annually to their Bishop. $^{38}$ During that time, Bishop and Church became an integral part of the system of marriage in England and played a special role in this system. ${ }^{39}$ In the middle of the $18^{\text {th }}$ century, the government approved the Marriage Act 1754 which tightened marriage rules requiring couples to reach the age of 21 before they could marry without their parent's consent and their marriage must be solemnised in a church. ${ }^{40}$ The Act became effective on March 26, 1754, and any marriage after that date not performed in accordance with the Act was void and would violate the laws and the couple would be subject to fourteen years' service on the King's plantation. ${ }^{41}$

In contrast, under Scottish law at that time, the parties could have a simple ceremony requiring two witnesses provided by both of the parties who were over the age of 16 and no parental consent was needed. $^{42}$ A Gretna Green marriage was recognised as valid in England, as was any contractual agreement to become husband and wife and was often witnessed by the local blacksmith in the town of Gretna Green in Scotland. ${ }^{43}$ Thus, couples from England who decided

cases except in matrimonial matters. According to Peter D. Johnson, the purpose of King William to separate the courts was due to phrase "God's Business was to be separated from Caesar's with the appropriate renders being made in different Courts". From the phrase, the intention of the Ruler during that time was to reduce the power of church.

42

"Family History for Beginners: Parish Register", Manchester and Lancashire Family History Society, Last modified January 3, 2011 http://www.mlfhs.org.uk/infobase/BeginRegisters.htm Ibid.

Rebecca Probert, Liam D'arcy Brown "The Impact of the Clandestine Marriages Act: Three Cases in Conformity," Continuity and Change 23(2)(2008),309 accessed June 11, 2013, doi: 10.1017/50268416008006759. Marriage Act 1754 also known as Lord Harwick's Act

Stuart J Stein, "Common Law Marriage: Its History and Certain Contemporary Problems", 276

Francis Steuart, “Gretna Green”, Jurid. Rev.41, 1929. 145.

Ibid. 
to get married could do so with less formality by crossing the border to the town of Gretna Green in Scotland. ${ }^{44}$

The Marriage Act 1754, in fact, was planned to prohibit such cross-border marriages which had become a source of humiliation for the families of the brides and the grooms in England. ${ }^{45}$ According to this Act, banns must be published in the church in which each party resided for three Sundays unless a license had been obtained earlier from the church. ${ }^{46}$ Parental consent must be acquired if the party was under the age of 21, unless the permission is impossible to obtain. Failure to get consent from the parent would render the marriage void except if the consent from the Lord Chancellor had been acquired by the party. ${ }^{47}$ In order to prove that a marriage was valid, each marriage entry must be registered in the parish register and duly signed by the couple with the presence of two witnesses and the officiating clergyman. ${ }^{48}$

Even though the enforcement of rulings in the Marriage Act 1754 was effective, it still could not prevent couples running away to Gretna Green. As the new law was strict and the consequence of failure to follow it was so harsh, many couples ran away by getting married in a clandestine manner in Gretna Green, Scotland. ${ }^{49}$ This usually happened when one of the parties was a minor and parental consent was not obtained. To prevent the overwhelming numbers of such marriages in England, the Marriage Act 1823 was enacted replacing the Marriage Act 1754 Act. $^{50}$ Under this new law, a marriage will be invalid if both parties knowingly and intentionally intermarried in any place other than the church wherein the banns might be published, or without the due publication of banns or gaining of a license, or if they knowingly and intentionally consented

44 Stuart J Stein, "Common Law Marriage: Its History and Certain Contemporary Problems", 276

45 Ibid., 275.

46 Ibid.,275.

47 Stephen Cretney et al., Principles of Family Law, $\left(7^{\text {th }}\right.$ Edition, Thompson Sweet \& Maxwell, 2003)11.

48 Ibid.

49 Jennifer M. Payne, "From Fleet Street to Gretna Green: The Reform of "Clandestine Marriage" under Lord Chancellor Hardwicke's Marriage Act of 1753", In the Southwestern Social Science Association Conference, (Dallas, Texas. March 24 1995)1. This paper can be retrieved at http://www.clandestine (accessed on 14 November 2013).

50 Nigel Lowe and Gillian Douglas, Bromley's Family Law, $10^{\text {th }}$ Edition, ( Oxford University Press, 2007) 53. 
to the solemnisation of the marriage by a person not in the holy order. $^{51}$ In all other cases, the marriage was to be valid notwithstanding any breach in the prescribed formalities. This Act remained the principal Act governing the formalities in England for over 125 years, although it was substantially amended during that time. $^{52}$

There were criticisms raised against the two earlier Acts that they forced Roman Catholics and Protestant dissenters to go through a religious form of marriage which might well be unacceptable to them. The growth of religious tolerance generally during the early years of the nineteenth century eventually led to the exclusion of the criticisms by the Marriage Act $1836 .{ }^{53}$ The combination of the Acts, the practice of tolerance and the introduction of the Births and Death Registration Act 1836 led to the introduction of a national system of registration and the introduction of a civil marriage. ${ }^{54}$

The main significance of the Act lies in the fact that it allowed marriages to be solemnised on the authority of the superintendent registrar's certificate (with or without licence) other than the rites of the Church of England. ${ }^{55}$ For the first time since the Middle Ages, English law recognised the validity of a marriage which was purely civil in character and completely divorced from any religious element by permitting the parties to marry in the presence of a superintendent registrar and a registrar of marriage and two other witnesses. ${ }^{56}$ The Act went further by allowing places of worship of members of denominations other than the Church of England to be registered for the solemnisation of marriages. ${ }^{57}$ Thus, the intervention of the Church was denied and it encouraged young couples to get married in England. Indeed, it discouraged young couples from running away to Gretna Green in Scotland and the Government at that time succeeded in controlling cross-border marriages.

In 1949, the Marriage Act 1949 was introduced in England. The purpose of the Marriage Act 1949 was to consolidate all laws before this into one Act. ${ }^{58}$ This Act had been amended several times until
Ibid.
Ibid., 53.
Ibid., 54.
Ibid., 54.
Ibid., 54.
Ibid.
Ibid.
Ibid. 
the Marriage Act was introduced in $1994 .{ }^{59}$ It consisted of several legal requirements regarding marriage and regulations of marriages and divorces. ${ }^{60}$ Nowadays, Gretna Green is only considered a historical place which once witnessed young couples who ran away to get married. It will be remembered as the place which gave birth to the modern Family Law in England.

\section{DISCUSSIONS AND CONCLUSION}

After analysing the different legal developments of cross-border marriages in Malaysia and England, the researchers have discovered that there are several distinctive features between cross-border marriages in both countries. The first observation would be that in Malaysia, cross-border marriages remains a problem because although there exists a requirement for the registration of a marriage, this does not affect the validity of such a marriage. The Islamic Family laws of each state in Malaysia coupled with the Fatwa given by the National Fatwa Council although acknowledging the importance of registering a marriage, however has not included it as a requirement for the validity of the marriage. This dilemma is actually due to the consideration given to the fate of the wives and children of the couples who have solemnised their marriages outside Malaysia. This also explains why section 31 of the Islamic Family (FT) Act gives a chance for couples who have married outside Malaysia to effect registration of the marriage within six months after the marriage had been solemnised. This is slightly different from the position in England whereby the problem of the Gretna Green marriages was settled by shifting the reliance on the religious rites of marriage to considering the registration of a marriage as a condition to the recognition to its validity. Indeed the approach had settled the problem of cross-border marriages in England, but to adopt the exact same method in Malaysia would pose some problems. This is because under Islamic law registration is not considered as one of the requirements of a valid marriage. To include it as a requirement would, to a large extent be controversial as it will be considered as amending not man made law but the law of Allah. Therefore, it is

$\begin{array}{ll}59 & \text { Ibid. } \\ 60 & \text { Ibid. }\end{array}$ 
submitted that the legal amendments to the marriage laws in England could not be accepted in toto the Malaysian context.

This leads us to the second observation that relates to the issue of the increase in the instances of cross-border marriages in Malaysia. Up till now, the Malaysian Government has still failed in its efforts to prevent marriages across the border and it is proven by the data provided by the Consulate General of Malaysia in Songkhla, Thailand. According to him, in year 2013, there were 3,485 Malaysian couples who solemnised their marriages in Southern Thailand. In contrast, in year 2014 the number increased to $3,831{ }^{61}$

A lesson that can be learnt from the English position is that there is a need to be firm but flexible in allowing couples to marry. The situation in England changed due to the shift in the law which made marriages between couples easier. When registration of a marriage was considered as proof of its validity and this could be carried out at the registration office and not only by priests, this stopped the need for couples to flee to Gretna Green. In the Malaysian context, since it might not be possible to amend the law and consider registration of a marriage to have an effect on its validity, then another mechanism will have to be considered. In actual fact the mechanism already exists in section 31 of the Islamic Family Law (FT) Act, which provides the punishment of a fine of RM1,000 or imprisonment for not more than six months or both. The main reason why this punishment has not deterred couples from continuing to solemnise the marriage at the borders of Thailand is because the fine is so low. Aside from that there has been no recorded cases on the imposition of the six months imprisonment in any of the reported cases.

Therefore, it is suggested that this problem can be addressed if the fine were to be increased to a more substantial amount. In order to do this, the powers of the Shari'ah courts need to be expanded, because as it is now the maximum fine that can be awarded is limited to RM5,000.00 which is still a nominal sum. Aside from that, the Shari'ah court judges should not shy away from awarding the punishment of imprisonment especially in cases which involve men who have already been married but have not informed their existing wife of the new marriage.

Aside from the legal sanctions, it is submitted that there is a need to educate the society on the detrimental effects of cross-border

61 "Bilangan Pasangan Malaysia Bernikah di Selatan Thai Meningkat," accessed March 16,2014, http:www.BHonline//. 
marriages where the parties to the marriage and their offspring are not able to claim for any maintenance. Meanwhile, there is also an equally pressing need to remind and educate parents, especially those of the brides to request for a reasonable mahar from the groom. The request for exorbitant mahar is also one of the main reasons why couples opt for cross-border marriages. As for cross-border marriages that occur due to polygamy, this too needs to be addressed with proper education on the need to respect the rights of the women and the true meaning of equality and how the act of marrying outside jurisdiction is in itself an unfair and unequal treatment towards both the first and subsequent wife.

In conclusion, cross-border marriages have created many problems for relevant government departments and also the society. If this phenomenon proliferates, it will cause disruption within the society because based on the cases decided by courts, these kinds of marriages will not last long. Most of such marriages occur due to failure to obtain the blessings of the parents of either bride or groom or both; and in the case of a polygamous marriage it results in unfairness towards the first wife and children. Finally, cross-border marriages lead to broken families, deep grudges and other negative connotations towards the development of the family. In the long run it leaves a negative effect on the well being of the family, which in turn will also leave a negative impact on the society and the development of the Ummah as a whole. 